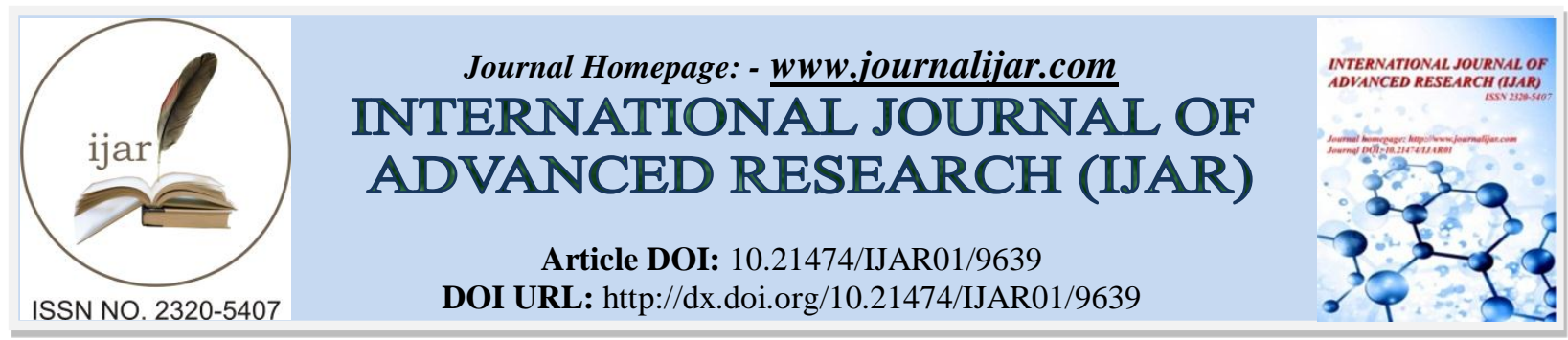

RESEARCH ARTICLE

\title{
ROLE OF PANCHAKARMA IN THE MANAGEMENT OF POLYCYSTIC OVARIAN SYNDROME.
}

\section{Dr.Poonam ${ }^{1}$, Dr.Priyanka Sharma ${ }^{1}$, Dr.Sanjay Gupta ${ }^{2}$ and Dr Parul Sharma ${ }^{3}$.}

1. PG Scholar, Department of Panchakarma, Rishikul Campus, UAU, Dehradun.

2. Associate Professor, P.G. Department of Panchakarma, Rishikul Campus, UAU, Dehradun.

3. Assistant Professor, P.G. Department of Panchakarma, Rishikul Campus, UAU, Dehradun.

\section{Manuscript Info}

Manuscript History

Received: 02 July 2019

Final Accepted: 04 August 2019

Published: September 2019

Key words:-

Polycystic ovarian syndrome (PCOS),

Bahudoshavastha, Panchkarma,

Acanthosis nigricans, Hirsutism.

\begin{abstract}
Polycystic ovarian syndrome is a complex endocrine disorder. It is prevalent in young reproductive age group of women. Incidence varies between $8-10 \%$, more common amongst infertile women. In present era due to sedentary life style, lack of physical activities, excessive stress and anxiety worsens the prognosis of the diseases. The heterogeneous disorder is characterised by excessive androgen production by the ovaries mainly, which interferes with the reproductive, endocrine and metabolic functions. The major clinical features are amenorrhoea, oligomenorrhoea, hirsutism, obesity, acanthosis nigricans and infertility. In modern science the treatment recommended is hormonal therapy and other drugs which cause adverse effect in due course of life. Rising in prevalence of PCOS has become a great cause of health concern as it is increasing the incidences of infertility and metabolic syndrome i.e. insulin resistance diabetes and dyslipidaemia at a younger age. According to Ayurveda the PCOS involves Kapha and Vata Dosha, Meda, Mamsa, Rakta Dhatus. In general it is considered as Bahudoshavastha, for which Ayurveda can play important role. Especially Panchakarma can have better results which includes Vamana, Virechana, Anuvasana, Niruha \& Nasya. Panchkarma may be better line of treatment for PCOS as it works on correcting the underlying root cause along with symptoms of the diseases. And along with shamana drugs its can give better results.
\end{abstract}

Copy Right, IJAR, 2019,. All rights reserved.

\section{Introduction:-}

Due to the increasing prevalence of PCOS in India, there is a need for early diagnosis and treatment that can help to relieve the symptoms .PCOS is probably fastest growing health hazard amongst women of reproductive age. Sedentary lifestyle, stress is contributing factors in its increasing prevalence. Polycystic ovary syndrome (PCOS) was described in 1935 by Stein and Leventhal as a syndrome manifested by amenorrhea, hirsutism and obesity associated with enlarged polycystic ovaries ${ }^{1}$. In India it is the most common endocrinopathy in female with reproductive age group with a prevalence of $8.10 \%^{2}$.PCOS is a condition characterized by hyperandrogenism and chronic oligo-anovulation ${ }^{3}$.PCOS is a multifactorial and polygenic condition ${ }^{4}$. Hirsutism may be clinically evident in $25 \%$ of the cases. PCOS is often associated with insulin resistance, dyslipidaemia, systemic inflammation and endothelial dysfunction ${ }^{5}$. This particular disorder is not described word to word in Ayurveda. PCOS associated some features are closely related with some of yonivyapadas and aartavadushti (menstrual pathologies).Modern 
management of PCOS is primarily targeted to correct the biochemical abnormalities. The treatment is confined to hormonal therapy and other drugs which cause many adverse effects in due course of time. According to Ayurveda the PCOS involves Kapha and Vata Dosha, Meda, Mamsa, Rakta Dhatus. In general it is considered as Bahudoshavastha, for which Ayurveda can play important role. Specially Panchakarma is the main line of treatment which includes Vamana, Virechana, Anuvasana, Niruha \& Nasya. Panchkarma may be better line of treatment for PCOS as it works on correcting the underlying root cause along with symptoms of the diseases. And along with shamana drugs its can give better results. Therefore Ayurvedic formulations from various Ayurvedic texts can be a better option for the definitive cure of PCOS.

\section{Pathophysiology:}

The exact pathophysiology if PCOS is not understood .but few factors can be considered as the contributing factors i.e hypothalamic-pituitary compartment abnormality, excess amount of androgen, anovulation, obesity and insulin resistance.In the context of yonivyapadas, there are four basic causative factors i.e. unwholesome lifestyle, menstrual disarrays, genetic disorders and some divine factors ${ }^{6}$, responsible for the manifestation of the syndrome.Mithyachara: Under this heading we can include Mithyaahara (faulty dietary habits) Mithyavihar (abnormal life style) both. In PCOS under the heading of abnormal diet we can include pizza, burger, bread, cold drinks, spicy, oily, junk food consumption. Abnormal life style may be faulty habits of sleep (Diwaswapna, Ratrijagrana), stress, competition pressure and other Mansikbhawa like Irshya, Krodh, Dwesh. We can see that all these are also causative factors for obesity, which play a very important role in appearance of this particular disease also. Pradushtartava: The word Aartva should be regard for ovarian hormones. As menstrual blood is a result of cyclic endometrial shedding under the influence of various hormones of HPO axis. In patients with PCOS ovarian compartment is the biggest contributor of androgens. Deregulation of CYP 17, the androgen forming enzyme in both adrenals and ovaries may be the central pathologic mechanism underlying Hyperandrogenism in PCOS.Bijadosha: Various chromosomal and genetic abnormality comes under this heading. Its genetic origins are likely polygenic and/or multifactorial. This is complex disorder that results from the interaction between multiple genetic and environmental factors. A high prevalence of PCOS or its features among first degree relatives is suggestive of genetic influences. Daiva: Unknown or idiopathic causes comes under this heading. Each cause has its own causative process, potential and mode of action. It is a disorder involving vata and kapha ${ }^{7}$ doshas along with Meda Dhatu dushti ${ }^{8}$. It is an endocrinological disease involving many systems.

\section{Clinical features:}

Increasing abdominal obesity, menstrual abnormalities, hirsutism, acne and infertility, acanthosis nigricans, hair- an syndrome etc ${ }^{9}$.

On the basis of Ayurvedic interpretation PCOS can be enumerated as Rasapradoshaja ${ }^{10}$ and Santarpanottha vyadhi ${ }^{11}$. Depending upon the symptoms it is Bahudoshavastha condition. Looking into the Dosha condition, the symptoms are more of kapha and Vata vitiation .Kapha gets vitiated causing Srotoavarodha and leading to Vata Vaigunyata.

\section{Management:}

In modern science the treatment recommended is hormonal therapy and other drugs which cause adverse effect in due course of life. Here comes the role of Ayurveda to provide safe and effective treatment. "Nidana Parivarjana" (avoid the causative factors) is said to be the very first step towards the management of PCOS. As it is considered as Bahudoshavastha so Sanshodhana is the main line of treatment. Chakrapani has commented on Acharya Sushruta, as Sanshodhana here is both Vamana and Virechana ${ }^{12}$.So Vamana followed by Virechana can be planned. It is Kapha Vata Pradhana condition associated with Agnimandavastha. Both the procedures, Vamana and Virechana are bio cleansing in nature, remove the metabolic waste, accumulated toxins and vitiated Dosha from the body. Thus they help in regularising the disturbed hormonal levels in the body. Vamana and Virechana also work on liver metabolism thus correcting the disturbed lipid levels. As per Kashyapa in oligo/hypomenorrhoea, amenorrhoea, Anuvasana Basti is the choice of treatment ${ }^{13}$. As vata is the main culprit in yonivyapada and Bati is the choice of treatment to control Vata.Basti works on the whole body and regulates the hypothalamic-pituitary-ovarian axis which helps in normalization of ovarian and menstrual cycle. Nasya: It is said that "Nasa Hi Shiraso Dwaaram". Hence Nasya would be the apt Shodhana procedure to tackle endocrine disorders, where hypothalamus or pituitary gland is involved. As Agnimandya, Medovriddhi, Apana Vayu and Kapha dushti plays the major role in the pathogenesis of the syndrome, so taking above fact into the consideration, Pathya Ahara-Vihara (dietary regimen \& exercise) is to be used.For Agnimandya and Aampachana, use of Trikatu Churna,Chitrakadi Gutika, Shadushana Churna, etc.are to be done for the Srotovarodha and to facilitate the Apana-Vatanulomana.For Medovriddhi, use of Takrarishta, Madhu like lekhanadravyas (scrapping agents) along with Yava, yavaka,kulattha etc. mentioned by 
Acharya Charaka in chikitsa of Atistula(obese). Moreover, lifestyle modification as well as regular exercise is also emphasized. Regular practice of Yoga i.e. Uttanapadasana, Sarvangasana, Halasana, Mayoorasana, Suryanamaskara, Vakrasana and Sheersasana, Sarvangasana, Sheersasana, Halasana, Bhastrika and Ujjayi pranayama should be adopted.

\section{Discussion:-}

Probable mode of action of different treatment modalities on PCOS:

Vamana Karma is the best therapy for the elimination of Kapha Dosha. According to Ayurveda, PCOS may be considered as Agni Vaishamyajanya Vikara (disease caused due to vitiation of metabolism) in general and Rasagni (metabolism at Rasa Dhatu level) and Medodhatvagni (metabolism at Meda Dhatu level) Mandya, As far as Dosha is concerned it is Kapha- Vataja disorder. As PCOS is metabolic disorder, Vamana helps to increase metabolism of body, thereby reducing weight and specifically act on liver metabolism which is the main site of hormone formation.

Virechana normalises the functions of Pita and Agni. Thus Sodhana helps to eliminate the vitiated Doshas and remove the Srotodushti existed at the level of Rasa, Rakta, Mamsa, Medas and Artavavahasrotas. This help in removing the Sanga, correction of the Agni, and normal functioning of Vata especially Apana and thus helps in proper formation and excretion of Artava (regularization of menstrual cycle and ovulatory cycle)and maintained its normal function.

Basti given through the rectal route enters into G.I tract which is considered as Enteric Nervous System. The Virya of Basti Dravya stimulates endogenous opioids which are usually present in G.I. tract. Endogenous opioids are a group of peptides, which play an important role in the ovarian cycle through the inhibitory effect on GnRH secretion. Other pituitary hormones are also modulated by opiates. $\beta$-endorphin has been best known opioid related to the reproductive system regulating variety of pituitary hormones including gonadotropins. It has a role in the regulation of the normal ovarian cycle ${ }^{14}$. Basti-stimulates the ENS which generates the stimulatory signal for CNS which in turn causes stimulation of Hypothalamus for GnRH and the Pituitary for FSH \& LH with the help of neurotransmitters. Parasympathetic activity is mainly responsible for the Apana Vayu activity. Basti stimulate the parasympathetic nerve supply which in turn helps for the maintenance of normal cycle ${ }^{15}$.

\section{Nasya:}

Drug through nasal route reaches the Shringataka Marma (Siro Antarmadhyam) and spreads through nose, ear, eye, and tongue into Shira (head) eliminate morbid Doshas and ultimately promotes the normal physiological function. Nasya may stimulate olfactory nerves and limbic system, which in turn stimulates hypothalamus leading to stimulation of Gonadotropin Releasing Hormone (GnRH) neurons, regularizing GnRH pulsatile secretion, leading to regular and normal menstrual cycle.

\section{Conclusion:-}

As PCOS is a life style disorder and its rising in prevalence has become a great cause of health concern as it is increasing the incidences of infertility and metabolic syndrome i.e. insulin resistance diabetes and dyslipidaemia at a younger age.so early diagnosis and treatment is need of hour.it can be well managed with Ayurvedic approach and life style modification. Panchkarma can help in cure of the disease without ill effects.

\section{Refrences:-}

1. 1.Dutta DC; Text book of Gynecology including contraception; edited by Konar Hiralal; New central book agency (P) Ltd. Kolkata; 6th ed; 2013; p - 440

2. Nidhi R, Padmalatha V, Nagarathna R, Amritanshu R; Prevalence of polycystic ovarian syndrome in Indian adolescent; J Pediatr Adolesc Gynecol. 2011 Aug;24(4):223-7. Doi: 10.1016/j.pag.2011.03.002. Epub 2011 May19.

3. Gambineri A, Pelusi C, Vicennati V, Pagotto U, Pasquali R; Obesity and the polycystic ovary syndrome; International journal of obesity and related metabolic disorders: journal of the international Association for the study of obesity[2002,26(7):883-896]

4. Dutta DC; Text book of Gynecology including contraception; edited by Konar Hiralal; New central book agency (P) Ltd. Kolkata; 6th ed; 2013; p - 440

5. Duleba AJ; Medical management of metabolic dysfunction; Steroids. 2012 Mar 10; 77(4); 306-11. Doi; 10.1016/j. steroids. 2011.11.014. Epub 2011Dec 13. 
6. Shastri PK \& Chaturvedi GN; Charaka Samhita, Vidyotini hindi commentary, Chikitsasthana 30/08; Chaukhamba Sanskrit Sansthana, Varanasi; reprinted ed -2012; p-841

7. Dalhana; Sushruta Samhita, Nibandh Sangraha and Nyaya Chandrika commentary, editor Jadavji T, Sharirasthana 2/4; Chaukhamba Sanskrit Sansthana, Varanasi; ed -2014; p- 344

8. Shastri PK \& Chaturvedi GN; Charaka Samhita, Vidyotini hindi commentary, Sutrasthana 28/15; Chaukhamba Sanskrit Sansthana, Varanasi; reprinted ed -2012; p-572

9. Dutta DC; Text book of Gynecology including contraception; edited by Konar Hiralal; New central book agency (P) Ltd. Kolkata; 6th ed; 2013; p - 440

10. Ibid.6 Charaka Samhita, Sutrasthana- 28/9-10, P. no.-571

11. Ibid.6 Charaka Samhita, Sutrasthana- 23/5,6,7, P. no.- 436

12. Chakrapani dutta sushruta-sanhita, sutra sthana with bhanumati commentary, edited by Vaidyajadavji Trikamji Acharya and pt.Nandkishor Sharma Bhishagacharya ,Published by Pt.ShyamsundarSharma, M.A.,Registrar Agra University and sec,Swami lakshmi Ram trustatNirnaya sagar press, Bombay,first edition 1939, chapter 15, shloka no.12,Pg no. 115

13. Vrddha Jivaka.Kashyapa Samhita, Sidhisthana, 7/11,revised by Vatsya, Sanskrit Introduction By Nepal Raaja Guru, Pandit Hemaraju Sharma, edt. by By Ayurvedalankar, Srisatyapala Bhisagacharya. Chowkambha Sanskrit Sansthan, Reprint: 2010.p. 167.

14. Rajan R., Postgraduate Reproductive Endocrinology, Jaypee Brothers, 4th ed., (2004)201-5.

15. Krupa R. Donga, Shilpa B. Donga and Laxmi Priya Dei, Role of Nasya and Matra Basti with Narayana Taila on anovulatory factor, Ayu, 34(1)(2013)81-85. 